\title{
INTERVENSI EMOTIONAL FREEDOM TECHNIQUE (EFT) UNTUK MENGURANGI NYERI POST OPERASI SECTIO CAESARIA (SC)
}

\author{
Lutfatul Latifah ${ }^{1}$, Dian Ramawati ${ }^{2}$ \\ ${ }^{1}$ Staf Pengajar Keperawatan Maternitas, ${ }^{2}$ Staf Pengajar Keperawatan Anak \\ Jurusan Keperawatan, Fakultas Kedokteran dan Ilmu-ilmu Kesehatan \\ Universitas Jenderal Soedirman, Purwokerto \\ E-mail:latifah.lutfatul@gmail.com
}

\begin{abstract}
ABSTRAK
Pendahuluan: Setiap ibu yang menjalani operasi Sectio Caesaria (SC) sering mengeluh nyeri post operasi yang sangat mengganggu, sehingga dapat menimbulkan dampak negatif seperti mobilisasi yang terbatas, bonding attachment antara ibu dan bayi terganggu, dan aktivitas Inisiasi Menyusui Dini (IMD) yang tertunda. Penelitian ini bertujuan untuk mengidentifikasi efek intervensi EFT atau terapi ketuk terhadap penurunan nyeri post SC. Metode: Penelitian ini menggunakan desain penelitian kuasi eksperimental dengan kelompok kontrol. Data dikumpulkan melalui pengukuran skala nyeri menggunakan Numeric Rating Scale (NRS) sebelum dan sesudah intervensi EFT. Responden yang terlibat sebanyak 30 orang, terdiri dari 15 orang masing-masing pada kelompok kontrol dan intervensi. Data dianalisis menggunakan uji t-test. Hasil: Rerata skala nyeri sebelum intervensi pada kelompok kontrol sebesar 5,20 dan pada kelompok intervensi sebesar 6,20. Rerata skala nyeri sesudah intervensi pada kelompok kontrol sebesar 5,00 dan pada kelompok intervensi sebesar 4,27. Terdapat perbedaan yang bermakna pada penurunan skala nyeri antara sebelum dan sesudah intervensi pada kelompok intervensi dengan $p$ value $=0,000(\alpha=0,05)$. Diskusi: Intervensi EFT merupakan salah satu metode non farmakologis yang dapat menurunkan skala nyeri pada ibu post operasi SC.
\end{abstract}

Kata kunci: nyeri post SC, EFT, penurunan skala nyeri, terapi non farmakologis

\section{ABSTRACT}

Introduction: Every woman who undergo Sectio Caesaria (SC) surgery for delivery their babies often complain about pain after the surgery and it become very distrubing. The effect of the pain cause mobilisation limitation, interrupting bonding attachment between mother and child, and postponning breastfeeding inititation. This study conduct EFT or tapping as the pain management in women post SC surgery.The aim of this study is to identify the effect of EFT or tapping for reducing pain after SC surgery. Methods: Quasy experimental with pre-post non randomized control group design was used in this study. The data been colleted using Numeric Rating Scale (NRS) to measure the pain in participants before and after EFT or tapping treatment. The number of participants was 30 mothers with 15 women in control and treatment group respectively. The t-test was used to analize the effect of the EFT. Results: The mean of pain scale before treatment in control group was 5.20 dan 6.20 for the treatment group. The pain scale after treatment in control group was 5.00 and 4.27 in treatment group. There was a significant difference between the reducing pain scale in treatment group with $p$ value $=0,000(\alpha=0.05)$. Discussion: EFT or tapping can be one of many non farmacologic treatment as complementer therapy to reduce pain after SC surgery.

Keywords: post SC pain, EFT, pain scale decline, non farmacologic therapy

\section{PENDAHULUAN}

Proses persalinan tidak selamanya dapat berjalan normal pervaginam, tetapi memerlukan tindakan seperti operasi Sectio Caesarea (SC). Pasien post SC akan mengeluh nyeri pada daerah insisi yang disebabkan oleh robeknya jaringan pada dinding perut dan dinding uterus. Nyeri post SC yang dialami ibu akan memberikan dampak negatif seperti terbatasnya mobilisasi, terganggunya ADL serta terlambatnya bonding attachment dan inisiasi menyusu dini.
Rasa nyeri akan menimbulkan berbagai masalah, menurut Hillan (1992) dalam Anggorowati (2007) bahwa 68\% ibu post sectio caesarea mengalami kesulitan dengan perawatan bayi, bergerak naik turun dari tempat tidur dan mengatur posisi yang nyaman selama menyusui akibat adanya nyeri. Rasa nyeri akan menyebabkan pasien menunda pemberian ASI sejak awal pada bayinya, karena rasa tidak nyaman selama proses menyusui berlangsung atau peningkatan intensitas nyeri setelah operasi (Batubara, 2008). 
Adapun dampak terhadap bayi adalah dalam pemberian ASI dan kurangnya perawatan bayi yang dilakukan oleh ibunya. Pemberian nutrisi untuk bayi berkurang karena tertundanya pemberian ASI sejak awal, respiratorik terganggu dan daya tahan imun rendah (Indiarti, 2009). Respons ibu dalam memberikan ASI kurang, maka ASI sebagai makanan terbaik bagi bayi dan mempunyai banyak manfaat bagi bayi maupun ibunya tidak dapat secara optimal.

Penatalaksanaan nyeri pada ibu post SC dilakukan dengan terapi farmakologis dan non-farmakologis. Penatalaksanaan nyeri dengan farmakologis menggunakan obat-obat analgesik narkotik baik secara intravena maupun intramuskular. Akan tetapi penggunaan rutin analgesik sebagai terapi untuk mengontrol nyeri tidaklah cukup, pasien masih merasakan nyeri yang berat sehingga diperlukan terapi dan intervensi lain sebagai tambahan.

Terapi komplementer akhir-akhir ini telah dikembangkan dan digunakan dalam dunia keperawatan sebagai alternatif pilihan penatalaksanaan nyeri secara nonfarmakologis. Penatalaksanaan nyeri secara nonfarmakologis yang digunakan antara lain dengan menggunakan relaksasi, hipnosis, pergerakan dan perubahan posisi, masase kutaneus, hidroterapi, terapi panas/dingin, musik, akupresur, aromaterapi, teknik imajinasi, distraksi dan Emotional Freedom Technique (EFT) (Potter \& Perry, 2006; Hakam, Yetti, \& Hariyati, 2009; Degirmen et al., 2010).
Beberapa penelitian membuktikan bahwa EFT efektif untuk mengatasi berbagai gangguan seperti kecemasan, menurunkan risiko terjadinya gangguan kesehatan fisik (seperti penyumbatan pembuluh darah, gangguan jantung) dan secara psikologis dapat mencegah kejadian penyakit atau gangguan jiwa (Syahfitriani, 2009; Ekowati, dkk., 2011).

Emotional Freedom Technique (EFT) atau dikenal dengan terapi ketuk (tapping) dikembangkan oleh Gary Craig. Sebuah terapi yang secara cepat, lembut dan mudah mengeluarkan emosi negatif yang dipercaya sebagai sumber dari masalah dan rasa sakit. EFT tidak menggunakan jarum, melainkan dengan menyelaraskan sistem energi tubuh pada titik-titik meridian tubuh dengan cara mengetuk (tapping) dengan ujung jari (Baker, Carrington \& Putilin, 2009). Alur diagram yang digunakan dalam terapi ketuk ini disajikan pada gambar 1 .

Terapi EFT terbukti dapat membantu individu mengatasi dan mengelola stress dampak dari stressor di lingkungan. Terapi EFT juga dapat menurunkan risiko terjadinya gangguan kesehatan fisik (seperti penyumbatan pembuluh darah, gangguan jantung) dan secara psikologis dapat mencegah kejadian penyakit atau gangguan jiwa (Syahfitriani, 2009). Ekowati dkk. (2011) menyebutkan bahwa terapi EFT dapat membantu menurunkan kecemasan pada pasien gangguan jiwa dan keluarganya.

Penelitian yang dilakukan oleh Hakam, Yetti, dan Hariyati (2009) menemukan bahwa

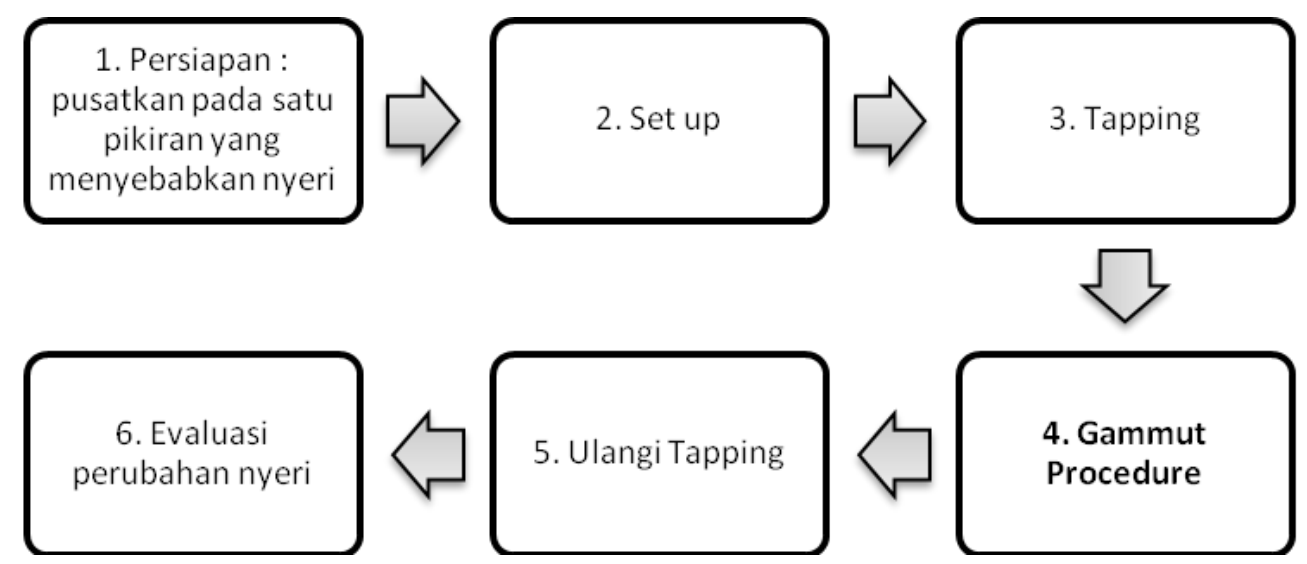

Gambar 1. Diagram Alur Terapi Ketuk (EFT) (Ekowati dkk., 2011). 
kombinasi terapi EFT dan analgesik lebih efektif dibandingkan dengan hanya terapi analgesik dalam menurunkan nyeri pada pasien penderita kanker, sehingga penderitaan pasien dapat berkurang. Literatur mengenai penelitian tentang pengaruh EFT terhadap penurunan nyeri pada ibu post SC belum ditemukan.

\section{METODE}

Desain dalam penelitian ini menggunakan quasy experiment non randomized pretest-postest with control group design. Penelitian ini dilaksanakan selama 5 bulan (bulan Agustus-Oktober 2013) di Rumah Sakit Umum Daerah Banyumas. Variabel dalam penelitian ini adalah terapi ketuk (EFT) sebagai variabel bebas dan skala nyeri pada ibu post SC sebagai variabel terikat.

Populasi dalam penelitian ini adalah seluruh ibu post SC di RSUD Banyumas. Populasi dalam penelitian ini berjumlah 1.252. Sampel dalam penelitian ini diambil secara purposive sampling yang memenuhi kriteria inklusi sebagai berikut: (1) ibu dengan post SC di RSUD Banyumas (2) ibu dalam keadaan sadar (compos mentis) (3) ibu yang bersedia menjadi responden. Adapun kriteria eksklusi pada penelitian ini adalah: (1) ibu yang memiliki masalah kesehatan lain (luka lain selain luka post SC, arthritis, plebitis, luka bakar, masalah kardiovaskular, respirasi atau masalah psikologis mayor seperti depresi atau paranoid) (2) ibu yang pada saat SC dilakukan general anestesi (3) ibu post SC yang mengalami preeklamsi/eklamsia (4) Ibu post SC yang menerima drip analgesik (5) ibu yang mengundurkan diri saat penelitian berlangsung. Sampel diambil dari semua subjek yang datang dan memenuhi kriteria pemilihan sampai jumlah subjek terpenuhi. Jumlah sampel yang diteliti adalah 30 responden.

Instrumen penelitian ini menggunakan lembar observasi NRS dan lembar observasi yang digunakan untuk mencatat data

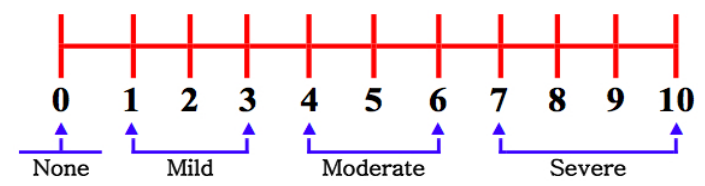

Gambar 2. Numeric rating scale (NRS)

demografi responden. NRS digunakan untuk mengukur tingkat nyeri berupa lapor diri responden dengan menyebutkan rentang skala nyeri 0-10 dari tidak ada rasa sakit hingga sakit tidak tertahankan. Numeric Rating Scale (NRS) digunakan untuk menilai intensitas atau keparahan nyeri dan memberi kebebasan penuh klien untuk mengidentifikasi keparahan nyeri (Potter \& Perry, 2006). NRS merupakan skala nyeri yang popular dan lebih banyak digunakan di klinik, khususnya pada kondisi akut, mengukur intensitas nyeri sebelum dan sesudah intervensi teraupetik, mudah digunakan dan didokumentasikan (Strong, et al, 2002 dalam Datak, 2008)

Penelitian diawali dengan mengumpulkan data demografik dan riwayat SC masing-masing responden pada lembar informasi pasien/lembar observasi, selanjutnya dilakukan pengukuran kala nyeri pada kelompok perlakuan dan kelompok kontrol sebelum dilakukan terapi ketuk, sekaligus mengobservasi ekspresi nonverbal responden terhadap nyeri. Intervensi/perlakuan dilakukan selama 30 menit pada hari pertama post SC (24 jam setelah dilakukan SC) pada kelompok perlakuan dengan memberi terapi ketuk satu jam sebelum pemberian analgesik. Dalam waktu 30 menit diberikan terapi sebanyak 3 kali putaran dari mulai tahap set up, sequence 1 , gammut procedure, dan sequence 2. Setelah intervensi selesai dilakukan, pengukuran skala nyeri kembali dilakukan pada kelompok perlakuan dan kelompok control. Setelah pengukuran skala nyeri kedua dilakukan, peneliti menganalisis dan menyimpulkan data hasil pengukuran, selanjutnya memberikan panduan terapi ketuk yang dapat dilakukan oleh responden secara mandiri baik pada kelompok kontrol maupun perlakuan. 
HASIL

\section{Karakteristik responden}

Responden yang terlibat dalam penelitian ini adalah ibu pascamelahirkan melalui operasi Sectio Cesaeria (SC) di Ruang Anggrek RSUD Banyumas. Responden yang terlibat pada penelitian ini sejumlah 30 orang dengan rincian 15 orang di kelompok kontrol dan 15 orang di kelompok intervensi. Adapun karakteristik responden disajikan dalam tabel 1 .

\section{Skala nyeri sebelum terapi ketuk}

Pada penelitian ini dilakukan pengukuran skala nyeri sebelum dilakukan terapi ketuk baik responden di kelompok kontrol maupun kelompok intervensi. Hasil pengukuran skala nyeri sebelum terapi ketuk terdapat pada Tabel 3. Hasil analisis pengukuran skala nyeri sebelum terapi ketuk memperlihatkan perbedaan skala nyeri pada kelompok kontrol yaitu rerata skala nyeri 5,20 dan rerata skala nyeri pada kelompok intervensi sebesar 6,20. Berdasarkan hasil analisis statistik tidak terdapat perbedaan yang bermakna skala nyeri sebelum terapi ketuk baik di kelompok kontrol dan kelompok intervensi $(p=0,446>\alpha=0,05)$ melalui uji homogenitas varians.

\section{Skala nyeri sesudah terapi ketuk}

Hasil pengukuran skala nyeri sesudah dilakukan terapi ketuk terdapat pada Tabel 4. Hasil analisis memperlihatkan terdapat penurunan skala nyeri baik di kelompok kontrol maupun kelompok intervensi. Penurunan

Tabel 1. Tabel Karakteristik Responden Bulan Agustus-Oktober 2013 di RSUD Banyumas

\begin{tabular}{lrrrr}
\hline \multirow{2}{*}{ No. Karakteristik } & \multicolumn{2}{c}{ Kelompok Kontrol } & \multicolumn{2}{c}{ Kelompok Intervensi } \\
\cline { 2 - 5 } & \multicolumn{1}{c}{$\mathbf{N}$} & $\mathbf{\%}$ & $\mathbf{N}$ & $\mathbf{\%}$ \\
\hline 1. Usia & 1 & 6,7 & 1 & 6,7 \\
a. $<20$ tahun & 9 & 60 & 12 & 80 \\
b. 20-35 tahun & 5 & 33,3 & 2 & 13,3 \\
c. $>35$ tahun & 1 & & & \\
\hline 2. Pendidikan & 4 & 26,7 & - & - \\
a. Tidak sekolah & 5 & 33,3 & 6 & 20 \\
b. SD & 3 & 20 & 4 & 26,7 \\
c. SMP & 2 & 13,3 & 2 & 13,4 \\
d. SMA & & & & \\
e. PT (S1/D3) & 15 & 100 & 9 & 60 \\
\hline Pekerjaan & - & - & 2 & 13,3 \\
a. IRT & - & - & 1 & 6,7 \\
b. Karyawan & - & - & 1 & 6,7 \\
c. Pedagang & - & - & 1 & 6,7 \\
d. Petani & - & - & 1 & 6,7 \\
e. PNS & & & & \\
f. Mahasiswa & 6 & 40 & 3 & 20 \\
\hline Riwayat SC & 9 & 60 & 12 & 80 \\
a. Pernah & & &
\end{tabular}

Tabel 2. Skala Nyeri Sebelum Terapi Ketuk Responden Bulan Agustus-Oktober 2013 di RSUD Banyumas

\begin{tabular}{lcccc}
\hline Kelompok Responden & Rerata & SD & SE & p-value \\
\hline Kontrol & 5,20 & 2,111 & 0,545 & 0,446 \\
Intervensi & 6,20 & 2,366 & 0,611 & \\
\hline
\end{tabular}


Tabel 3. Skala Nyeri Sesudah Terapi Ketuk Responden Bulan Agustus-Oktober 2013 di RSUD Banyumas

\begin{tabular}{lccc}
\hline \multicolumn{1}{c}{ Kelompok Responden } & Rerata & SD & SE \\
\hline Kontrol & 5,00 & 1,309 & 0,338 \\
Intervensi & 4,27 & 1,438 & 0,371 \\
\hline
\end{tabular}

Tabel 4. Perbedaan Skala Nyeri Responden Post Operasi SC Bulan Agustus-Oktober 2013 di RSUD Banyumas

\begin{tabular}{lccc}
\hline \multicolumn{1}{c}{ Kelompok Responden } & Rerata & SD & p-value \\
\hline Kontrol & 0,2 & 1,146 & 0,510 \\
Intervensi & 1,933 & 1,624 & 0,000 \\
\hline
\end{tabular}

skala nyeri pada kelompok kontrol sebesar $-0,20(5,00-5,20)$, sedangkan pada kelompok intervensi mengalami penurunan skala nyeri yang lebih besar yaitu $-1,93(4,27-6,20)$ dibandingkan dengan skala nyeri sebelum dilakukan terapi ketuk pada responden.

\section{Perbedaan skala nyeri antara sebelum dan sesudah terapi ketuk}

Hasil analisis dengan uji t-test memperlihatkan tidak ada perbedaan yang bermakna pada skala nyeri pada kelompok kontrol ( $\mathrm{p}$ value $=0,510 ; \mathrm{p}>\alpha=0,05$ ) Namun, terdapat perbedaan skala nyeri yang sangat bermakna antara sebelum dan sesudah dilakukan terapi ketuk pada responden di kelompok intervensi ( $\mathrm{p}$ value $=0,000 ; \mathrm{p}<$ $\alpha=0,05$ ). Hasil analisis perbedaan skala nyeri terdapat pada Tabel 5 .

\section{PEMBAHASAN}

\section{Karakteristik Responden}

Hasil penelitian menemukan bahwa mayoritas usia responden antara 20-35 tahun. Smeltzer dan Bare (2002) menyatakan bahwa cara seseorang berespons terhadap nyeri dipengaruhi oleh jumlah nyeri yang dialami selama rentang hidupnya. Usia memiliki hubungan dengan pengalaman nyeri seseorang, kelompok anak-anak dan lansia dapat terpengaruh bagaimana cara bereaksi terhadap nyeri. Orang dewasa akan mengalami perubahan neurofisiologis dan mungkin mengalami penurunan persepsi sensorik stimulus serta peningkatan ambang nyeri (Potter \& Perry, 2006).

Tingkat pendidikan responden dalam penelitian ini terbanyak adalah SMP. Pendidikan berpengaruh terhadap pemberian respons pada sesuatu yang datang dari luar. Seseorang yang mempunyai pendidikan tinggi akan memberikan respons lebih rasional dibandingkan dengan orang yang memiliki tingkat pendidikan menengah atau rendah. Sehingga kesadaran dan usaha pencapaian/ peningkatan derajat kesehatan lebih baik pada kelompok berpendidikan tinggi dibandingkan kelompok berpendidikan menengah atau rendah. Asri (2006) menyatakan bahwa tingkat pendidikan mempengaruhi persepsi seseorang dalam merasakan nyeri pada proses modulasi yaitu interaksi antara sistem analgesik endogen dengan input nyeri yang masuk ke kornu posterior medulla spinalis. Proses modulasi inilah yang menyebabkan persepsi nyeri menjadi subjektif dan ditentukan oleh makna atau arti suatu input nyeri.

Sebagian besar responden belum pernah mengalami persalinan SC. Potter \& Perry (2006) menyatakan bahwa apabila seseorang mengalami nyeri dengan jenis yang sama (pernah mengalami SC), maka akan lebih mudah bagi orang tersebut melakukan tindakan untuk menghilangkan atau mengurangi nyeri. Berbeda dengan yang dikemukakan oleh Harsono (2009), yang menyebutkan bahwa riwayat $\mathrm{SC}$ tidak mempengaruhi respons seseorang terhadap nyeri yang dirasakan. Hal ini ditemukan dalam penelitian ini di mana terdapat responden yang sudah dua kali 
mengalami SC merasakan nyeri yang lebih hebat dan mendemonstrasikan perilaku koping tidak efektif dibandingkan dengan pengalaman SC sebelumnya.

Karakteristik responden dalam penelitian ini adalah ibu rumah tangga, PNS, dan karyawan. Seluruh responden pada kelompok kontrol dan mayoritas responden pada kelompok intervensi bekerja sebagai ibu rumah tangga. Pekerjaan rumah tangga seperti memasak, mencuci baju, membersihkan rumah dan menyetrika termasuk dalam aktivitas fisik. Karim (2002) menyatakan bahwa aktivitas fisik memiliki manfaat untuk kekuatan otot dan penambahan massa otot. Hasil penelitian ini menemukan mayoritas responden bekerja sebagai ibu rumah tangga yang dapat disimpulkan memiliki karakteristik aktivitas fisik yang sama, sehingga fleksibilitas yang mempengaruhi kontraksi dan relaksasi otot cenderung memiliki kesamaan. Dengan demikian, tingkat nyeri ibu rumah tangga dimungkinkan berada pada rentang yang sama.

\section{Pengaruh EFT/Terapi Ketuk terhadap Penurunan Skala Nyeri}

Hasil analisis pada kelompok intervensi menunjukkan bahwa terdapat pengaruh signifikan terapi EFT terhadap penurunan skala nyeri dengan nilai signifikansi 0,000 . Sementara itu, hasil analisis pada kelompok kontrol tidak menunjukkan perbedaan yang signifikan dengan nilai $p$ value 0 , 510. Penurunan skala nyeri pada kelompok intervensi setelah dilakukan terapi sebesar 1,93, sedangkan pada kelompok kontrol penurunan sebesar 0,20. Hal tersebut menunjukkan bahwa penurunan skala nyeri lebih besar pada kelompok intervensi dibandingkan pada kelompok kontrol, sehingga dapat disimpulkan bahwa terapi EFT dapat menurunkan skala nyeri pada ibu post SC.

Dasar teori EFT mengatakan bahwa emosi negatif disebabkan oleh gangguan pada sistem energi tubuh (sistem meridian). Ketukan atau tapping pada titik-titik akupunktur sambil berfokus pada emosi negatif, dikatakan dapat menyeimbangkan energi tubuh (Craig, 2008). Brattberg (2008) mengatakan bahwa walaupun tidak bisa dijelaskan cara kerjanya, akan tetapi secara klinis ditemukan bahwa pasien yang hanya memikirkan masalah yang dihadapinya, memiliki respons emosional yang berbeda dibandingkan dengan pasien yang dilakukan EFT di mana perubahan sikap terhadap nyeri terlihat nyata. Hal ini dimungkinkan bahwa EFT membantu individu untuk menerima masalah yang tidak dapat diterima oleh individu.

Dari pandangan medis dunia barat, sulit dipahami tentang terapi pada titik meridian, akan tetapi penjelasan tentang efek dari EFT dapat diterima. D. Feinstein dalam Batterberg (2008) menyatakan bahwa EFT mempunyai kemampuan untuk mengurangi stimulasi yang berlebihan pada sistem limbik. Ruden (2005) menyimpulkan bahwa stimulasi pada titik akupunktur mengeluarkan serotonin di dalam amygdala dan di korteks prafrontal. Kemungkinan lain berasal dari hasil penelitian yang menunjukkan bahwa kadar endomorphin-1, beta endorphin, enkephalin dan serotonin meningkat di dalam plasma dan jaringan otak setelah dilakukan akupunktur (Cabyoglu, Ergene \& Tan, 2006, dalam Batterberg, 2008). Hasil observasi yang dilakukan oleh Cabyoglu, Ergene \& Tan juga menunjukkan bahwa peningkatan endomorphin-1, beta endorphin, enkephalin, serotonin dan dopamin menyebabkan efek analgesik, sedasi dan penyembuhan pada fungsi motorik sama seperti efek immunomodulator pada sistem imun. Sehingga dapat dimungkinkan bahwa aspek akupressure pada EFT memproduksi hasil yang sama. Stimulasi non-noxious pada kulit memicu efek analgesik dan sedatif yang dialirkan melalui aktivasi mekanisme oxitosinergis (oxytocinergic mechanisms) (Uvnäs-Moberg, Bruzelius, Alster \& Lundeberg, (1993). Lebih spesifik lagi, K. Uvnäs-Moberg, MD, profesor pada Institut Karolinska, Stocklom, Swedia, menunjukkan bahwa stimulasi sensori non-noxious berhubungan dengan interaksi sosial yang bersahabat (ketika terapi dilakukan oleh terapis) menginduksi respons psikofisiologis di mana oksitosin diproduksi yang meningkatkan efek sedasi, relaksasi dan menurunkan aktivitas simpatoadrenal 
(sympathoadrenal). Dalam penelitian tentang efek EFT terhadap PTSD yang dialami oleh korban kecelakaan kendaraan bermotor yang dilakukan oleh Swingle, Pulos dan Swingle (2004), menunjukkan penurunan stimulasi korteks frontal kanan dalam menterapi trauma menggunakan EFT. Akan tetapi masih tetap tidak dapat menentukan jika EFT mempunyai efek spesifik secara fisiologis.

Meskipun EFT tidak memiliki efek psikologis yang spesifik, hasil penelitian ini menunjukkan penurunan skala nyeri yang signifikan pada kelompok intervensi. Sebagian responden menjadi lebih tenang dan menyatakan menerima dan pasrah terhadap rasa nyeri yang dialaminya setelah dilakukan EFT. Kata-kata afirmasi memicu penerimaan diri. Seperti yang dikatakan oleh salah seorang responden bahwa ketika melakukan afirmasi dia lebih pasrah dan menerima apa yang sedang dirasakannya. Pada beberapa individu, ketakutan akan nyeri lebih hebat dibandingkan dengan nyeri itu sendiri. Efek bawah sadar dari EFT mempengaruhi individu sehingga ketakutan akan nyeri berubah menjadi penerimaan.

\section{KESIMPULAN DAN REKOMENDASI}

Berdasarkan hasil penelitian, dapat disimpulkan bahwa EFT atau terapi ketuk yang dilaksanakan dalam waktu 30 menit selama 3 sesi dapat menurunkan skala nyeri pada pasien post SC hari pertama. Penurunan nyeri post SC yang didapatkan pada ratarata responden. Teknik EFT atau terapi ketuk ini dapat diajarkan kepada perawat ruang perawatan ibu post partum maupun pada ibu post SC sebagai salah satu terapi komplementer non farmakologis.

\section{DAFTAR PUSTAKA}

Anggorowati, dkk. 2007. Efektivitas pemberian intervensi spiritual "spirit ibu" terhadap nyeri post sectio caesarean (SC) pada RS Sultan Agung dan R Roemani Semarang. Journal Media Ners Vol. 1, No. 1, Tahun 2007.
Asri, S. 2006. Perbedaan pengaruh pemberian anestesi spinal dengan anestesi umum terhadap kadar gula darah. Karya tulis ilmiah, Universitas Diponegoro.

Baker, A.H, Carrington, P. \& Putilin, D. 2009. Theoretical and Methodological in Research on Emotional Freedom Techniques (EFT) and Other Meridian Based Therapies. Psychology Journal. Vol. 6, No. 2, pp. 34-46.

Batubara, dkk. 2008. Hubungan pengetahuan, Nyeri Pembedahan Sectio Caesaria dan Bentuk Puting dengan Pemberian Air Susu Ibu Pertama Kali Pada Ibu Post Partum. Jurnal Keperawatan Soedirman (The Soedirman Journal of Nursing), Volume 3 No. 2 Juli 2008.

Brattberg, G. 2008. Self-administered EFT (Emotional Freedom Techniques) in Individuals With Fibromyalgia: A Randomized Trial. Integrative Medicine Vol. 7, No. 4, pp. 30-35.

Cabyoglu, M.T., Ergene, N. \& Tan, U. 2006. The mechanism of acupuncture and clinical applications. Int $J$ Neurosci. 116(2): 115-125.

Craig,G. 2008. EFT Manual. Available at: http://www.emofree.com/ downloadeftmanual.

Degirmen, et al. 2010. Effectiveness of foot and hand massage in post cesarean pain control in a group of Turkish pregnant women, Applied Nursing Research, Vol. 23, pp. $153-158$.

Ekowati, W dkk. 2011. Terapi Ketuk untuk Mengurangi Tingkat Kecemasan Bagi Keluarga Penunggu Pasien Jiwa. Laporan Penelitian.

Hakam, M., Yetti, K. \& Hariyati, Rr. T.S. 2009. Intervensi Kebebasan Teknik Kebebasan Spiritual dan Emosional untuk Mengurangi Rasa Nyeri Pasien Kanker. Makara Seri Kesehatan. Vol 13, No. 2.

Harsono. 2009. Faktor-faktor yang mempengaruhi intensitas nyeri pascabedah abdomen dalam konteks asuhan keperawatan di RSUD ade mohammad djoen sintang. Thesis, Universitas Indonesia.

Indiarti, M.T, 2009. Panduan lengkap kehamilan, persalinan dan perawatan bayi. Yogyakarta: Diglossia Media. 
Isselbacher, J. K. 1999. Prinsip-prinsip ilmu penyakit dalam (Harrison's principles of internal medicine). Edisi 13. Volume 1. Jakarta: EGC.

Karim, F. 2002. Panduan kesehatan olahraga bagi petugas kesehatan. Jakarta: Departemen Kesehatan Komunitas.

Potter \& Perry. (2006). Buku ajar fundamental keperawatan konsep, proses, dan praktik. Edisi 4. Jakarta: EGC.

Pratiwi, R. 2012. Penurunan intensitas nyeri akibat luka post sectio caesarea setelah dilakukan latihan teknik relaksasi pernapasan menggunakan aroma terapi lavender di rumah sakit al islam bandung. Skripsi, FIK Unpad.

Purwandari, 2009. Pengaruh terapi latihan terhadap penurunan nilai nyeri pada pasien post sectio caesarea.
Skripsi: Universitas Muhammadiyah Surakarta.

Ruden, R.A. 2005. Neurobiological basis for the observed peripheral sensory modulation ofemotional responses. Traumatology.; 11(3): 145-158.

Smeltzer, S.C, \& Bare, B.G. 2001. Buku ajar keperawatan medikal bedah. Jakarta: EGC.

Swingle, P.G., Pulos, L. \& Swingle, M.K. 2004. Neurophysiological indicators of EFT treatment of post-traumatic stress. Subtle Energies Energy Med; 15(1): $75-86$.

Uvnäs-Moberg, K., Bruzelius, G., Alster, P. \& Lundeberg, T. 199). The antinociceptive effect of non-noxious sensory stimulation is mediated partly through oxytocinergic mechanisms. Acta Physiol Scand. 149(2): 199-204. 